\title{
How Managers Can Conduct Planned Change in Self-organising Systems: Actor Network Theory as a Perspective to Manager's Actions
}

\author{
Robert J. Blomme \\ Centre for Leadership and Management Development, Nyenrode Business Universiteit \\ Straatweg 25, 3621 BG Breukelen, The Netherlands \\ Tel: 31-6-2043-5206Ｅ-mail: r.blomme@nyenrode.nl
}

Received: August 14, 2012

Accepted: August 29, 2012

Online Published: September 12, 2012

doi:10.5430/ijba.v3n5p9

URL: http://dx.doi.org/10.5430/ijba.v3n5p9

\begin{abstract}
This article discusses why the majority of change initiatives in organisations fail in accomplishing the intended goals and expectations defined by its members and gives directions for a new perspective of organisational change and the leadership role of managers in this. First this paper carries out a literature review of notions from Weick's sensemaking concept and Actor Network Theory to develop a perspective of emergent organisational change and the role played by managers. The limitation of the influence managers' actions have in the organisational context is discussed. However, an important characteristic of the manager as a formal leader is also incorporated in this; leaders are able to reduce the equivocality of their followers and together with their followers they can construct new meanings by acting together. An important conclusion is that managers may become more effective in change processes when they are willing to step into the role of sensegivers.
\end{abstract}

Keywords: Equivocality, Structuration, Sensemaking, Sensegiving, Actor Network Theory, Emergent change, Organisational change

\section{Introduction}

This paper discusses why the majority of change initiatives in organisations fail in accomplishing the intended goals and expectations defined by its members and gives directions for a new perspective of organisational change and the role of managers in this.

In their daily work, managers are often faced with change initiatives which fall short or which do not achieve the desired result. These initiatives are often developed from a blueprint and are carried out in project form. Attempts by managers to implement change initiatives often meet with resistance from within the very organisation in which the change initiatives were developed. The original goals of the planned organisational change may also change during its implementation. It seems that the context in which the change should take place has changed so much that the execution of the change plan often creates more problems than it solves. In such cases, modifying the objectives is a way of dealing with the changing context. However, the original project plan can no longer be adjusted because it will only have partly been completed. The objectives, planning and execution will no longer be consistent. Other researchers and practitioners support these observations (see, for example, Devos, Buelens, \& Bouckenooghe, 2007; Hailey \& Balogun, 2002; Higgs \& Rowland, 2001, 2005). In these circumstances, managers will resort to better diagnostic methods and will devise a plan of change which matches the outcomes of the diagnosis (See also, Ten Have, Ten Have, \& Janssen, 2009). However, whether managers are able to take this dynamic into consideration and are able to anticipate these changes through competent project management and by being able to make adjustments when necessary is questionable. In reality it seems that when it comes to planned organisational change the ability to anticipate and make adjustments is wanting.

This article will argue that the manager can never separate himself from the change context in which he is acting. This article will make an even stronger claim and argue that the organisational problems that the manager is faced with are in part caused by the interventions he has made in the past. To support this claim, section 2 presents a different approach to organisational change and the role of the manager. First the traditional approach will be discussed from a critical point of view. After this a conception of emergent change and self-organisation will be presented using the ideas of Weick and the ANT approach to support it. This concept holds that organisations can be viewed as self-organising actor networks in which change takes place on a continuous and autonomous basis. 
In section 3 we introduce a perspective on organisational change in self-organising networks. We will use the ANT approach to elaborate this concept. We will discuss this concept and will derive a number of managerial implications which can be drawn with respect to organisational change and the role of managers. In section 4 we will draw conclusions.

\section{Organisations as Self-organising Actor-networks}

\subsection{Connected Behaviour and Self-organisation}

From the traditional perspective, the manager views the organisation as an objectifiable entity (Blomme, 2003). Management can be seen as the formal leaders in an organisation (French \& Raven, 1959) which is supported by the traditional concept of leadership as 'interpersonal influence' (Marion \& Uhl-Bien, 2007; Uhl-Bien \& Marion, 2007) and by the perspective that organisations are hierarchically run from the top downwards and emphasize intentional change (Hales, 2007; Stoker, 2006). Managers are able to view the organisation in which change will be taking place objectively, make a diagnosis about the object and manipulate it. This approach supports the modernist assumption that objective knowledge is the way to understand reality. Objective knowledge involves disconnecting the subject from the object (Kaulingfreks, 1999). By observing the world around us and making it objectifiable, we can make this world divisible, quantifiable and cognizable. A pervasive notion in modernism is the idea that we can become independent of the world and control it. 'Progress' is an important motive behind this way of thinking. 'Modernist' conveys the idea that we are moving with the times so that we can ultimately achieve what is 'makeable'. In this approach, attention is paid to the independence of the manager with respect to the change object, that is, the organisation or part of it. This perspective also puts forward the idea that the means of change - the instruments such as structure, procedures and guidelines - are separate from the object of change. These two separations place a great deal of emphasis on the degree of control and rationalisation organisations have (see for example, Child \& Smith, 1987; Greenwood \& Hinings, 1996; Kaulingfreks, 1999). A number of things can be said about the idea of the organisation as an entity. Tsoukas (2003), for example, claims that an organisation is the ordering of individual behaviour. Thus there is no difference between the organisation and those who make up the organisation. An organisation consists of people and these same people make up the organisation, which means that the organisation cannot be an objective entity. How can people change an organisation if they themselves are part of it (Tsoukas, 2003; Haridimos Tsoukas \& Chia, 2002)? Law provides an explanation for this (Law, 2004). All the events in a social system are embedded in a social context. How people act in such a context is the result of the experiences and artefacts which people have accumulated in the past. Law stresses that the way in which people attempt to understand their reality also creates the reality they want to understand. Linstead and Thanem (2007) also criticise the modernist distinction between organisation and change. Change is seen as the opposite of organisation. In the beginning the organisation is stable; change is then induced in the organisation. The change process is brought to a halt once the appropriate ultimate state of organising has been achieved (Linstead \& Thanem, 2007). Elaborating on the work of Gibson Burrel (Burrel, 1996, 1997), they maintain that change and the organisation are not opposites: the organisation itself is precisely where changes continuously take place. Therefore a manager does not change the organisation. His actions are the result of the change process which he himself has brought about.

The picture of the organisation as a platform for change is supported by Maturana and Varela (1987). Organisational change is a continuous process of self-organisation. In their book, The Tree of Knowledge, Maturana and Varela provide a biological basis for the self-organisation of social systems. Self-organisation is a principle of ordering. This means that the survival and the order of what organises itself is solely determined by what organises itself. As a result, there is no single external reference on which order and survival are based. Maturana and Varela define a self-organising system on the basis of three self-organising systems of three different orders: the cell, the organism and the self-organising system. They describe how a cell functions as a system of the first order using a theory which they call 'autopoeisis' and extend this principle to a system of the second order which they call 'metacellular': the organism. A system of the third order is formed by a group of organisms. If these organisms are people, this can be referred to as a social system and - by extension - a group or organisation. Maturana and Varela also regard the third-order system as one which is self-organising (Maturana \& Varela, 1987). Therefore it would seem that a transcendent reality responsible for change in a social system does not exist; rather, it is the immanent social system which initiates change.

\subsection{Emergence}

The central idea of self-organisation is that the order of behaviour is emergent (Drazin \& Sandelands, 1992). Drazin and Sandelands (1992) postulate that structure or order emerge from the interactions of participants within a system. We will refer to the system's participants as agents (Yolles, 2006). Collins claims that this order has a conceptual or 
cognitive status; it exists as a mental representation and does not only constitute social interactions between individuals (Collins, 1981). Berger and Luckman argue that social structure is a mental construct as displayed by categorisation schemes used by agents as a means to make sense of their flow of experience (Berger \& Luckman, 1966). Emergence is not a static property of a system but a perceived moment in time (Abraham \& Shaw, 1987; Gleick, 1988). Drazin and Sandelands (1992) argue that an emergent order is based on its own logic. This logic exists as rules played out by the agents (Drazin \& Sandelands, 1992). The process of emergence can also be explained as the process of structuration; structure or order is not an omnipresent force that continuously reproduces itself but a process in which the agents are empowered by the logic provided to act. Moreover, with their capacities and inclination, agents are able to change that logic when interacting with other participants and with the establishment of a new logic, a new related structure emerges (Giddens, 1991). Structuration is an ongoing process that requires continuous adaptation and adjustment. Hence, change can be defined as the breakdown of an old logic and structure and the establishment of a new logic and related structure (Mezias \& Glynn, 1993). The environment functions as an important input for emergent change. Exogenous change exerts pressures on the behavioural system which determines its own emergent actions. These actions are then further shaped by internal and external forces with a further continuation of the cycle. Emergent change will take place when exogenous change leads to a decrease in the system's performance, and agents are aware that the current logics are no longer working effectively (Mezias \& Glynn, 1993). Hence, emergent change can be defined as the structuration process of agents in which the structure and underlying logics are perceived as unworkable and in which agents make sense of new logics and related structures that will eventually work (Knights \& Willmott, 1989). Therefore a manager does not change the organisation. His actions are the result of the change process which he himself has brought about because as an agent he is part of the change context itself. Hence, we could say that the traditional perspective of change and the change manager is not applicable anymore when it comes to bringing about change effectively in organisations. This explanation enables us to characterise emergent change. First we will address the incremental aspect of emergent change. In contrast to transformational perspectives of change in which organisations redefine structures and new business processes (e.g., Child \& Smith, 1987; Royston Greenwood, Hinings, \& Suddaby, 2002), emergent change passes through small steps unfolding new logics and structures as it does so. We could also argue that change is an unplanned process, which contradicts the theories of planned change, such as those found in the institutional perspective (Greenwood \& Hinings, 1996), or in the resource-based value perspective (Sirmon, Hitt, \& Ireland, 2007). Emergent change is a reaction to the perceived exogenous changes by the system's agents. We could also conclude that from an emergent perspective, change is remedial rather than developmental. Emergent change will take place when the underlying logics cannot help in dealing with an exogenous change which results in a decline in performance to an unacceptable level (Mezias \& Glynn, 1993). Without these exogenous changes agents are inclined to validate their own logics. This is different from the developmental change perspective in which agents are willing to change their logic without there being an exogenous threat (Drazin \& Kazanjian, 1990; Kallunki \& Silvola, 2008; Miller \& Friesen, 1984). As such, emergent change can be characterised as incremental, unplanned and remedial.

Applying the insights discussed above regarding actor networks to organisations provides the first conclusion that an organisation is an immanent system. Changes which take place in an organisation are initiated by the organisation itself. In this sense an organisation is a closed system. Organisational change therefore requires the actors to behave differently and this means that there will be a shift in the way in which individual behaviour is connected. The change in organisational behaviour will bring about an ordering of behaviour. This organisational change is a self-organising process and we call this emergent change in line with Chiles, Meyer and Hench (2004). At the centre of this process of self-organisation is its self-referential character, which means that any changes which may be produced by the organisation must contribute to its continued existence and growth. Therefore there is no transcendent reality outside the organisation itself to impose change. Organisations are immanent actor networks in which change occurs of its own accord.

\section{Organisational Change in Self-organising Actor Networks}

\subsection{Introduction}

If we apply this discussed perception of emergence to change in organisations, we can raise the question what the consequences are for managers. Or to put it more straight forward: 'How can managers propel change in self-organising actor networks?'. As we have contrasted this emergent perspective with the more traditional planned changed approaches, we cannot make use of the intervention methods aligned with the latter. The most important conclusion we can draw about planned change is that it is never initiated by a single acting individual. It is the actor network which allows change to develop; the word 'planned' is the meaning which the actors derive from these new behavioural connections. The words 'planned' and 'implementation' have been borrowed from the traditional 
concept of the organisation as a hierarchy and bureaucracy; they are meanings for the shared interactions and dependent relations of the different actors. Emergent change drives planned change. Hence, the emergent perspective holds a new approach and a new framework for managers who are about to bring change in organisations. For the development of a new framework we need to examine how change in an actor network works and what this change propels. In the next sections we will introduce two concepts which may be an answer to these questions: the Actor Network Theory of Bruno Latour and his colleagues, and the sensemaking concept of Karl Weick.

\subsection{Actor Network Theory}

The Actor-Network Theory (ANT) originates from the ideas put forward by Latour, Callon and Law (see for example, Callon, 1986; Fotaki, Böhm, \& Hassard, 2010; Latour, 2005; Law, 2004; Law \& Hassard, 1999) who attempted to explain the development of scientific thinking and acting by using the influence of available technological resources and particular actors on scientists' actions and way of thinking as a basis. Various researchers have used Actor-Network Theory to study innovation processes (Garud \& Karoe, 2001) and organisational change (Harisson, Laplante, \& St-Cyr, 2001). In the ANT approach, the actor's environment is viewed as a language of texts which is given meaning. It is not only the conversations that are viewed as texts, but also all the actions of other actors. In the ANT approach not only are human actors considered to be part of the enacted environment and an important source for sensemaking, but 'inanimate actors' such as technology and material artefacts are too (see also Latour, 2005). Latour (2005) argues that human actors and 'inanimate' materials are connected with each other just as human actors are.

He calls both human actors and the inanimate outcomes of human behaviour 'actants' and these form the nodes in the actor network. Following Latour (2005), we define ideas, knowledge, facts, materialized objects such as technology and reports, political decisions, but also objects and perceptions in relation to objects of nature as these inanimate outcomes. Latour gives an example when discussing the issue of the ozone layer depletion, in which he argues that the existence of a hole in the ozone layer and the perceived threat are subject to an interaction process between human actors, but one in which the inanimate actors - such as reports, ideas and knowledge - also play a very important role (Latour, 2005). Inanimate outcomes do not have meaning in themselves, but acquire meaning as a result of the actions which human actors have taken with the use of other inanimate actors. Normally, we do not have a clue about these actions and the inanimate outcomes to which they lead. That is why we consider these outcomes to be a sort of black box. This does not mean, however, that it is not possible to unhide these actions in these networks. All the phenomena involved - new ideas, knowledge, facts, technological objects, political decisions - can only emerge as a signifying object when we understand the actions and the network in which these take place which lead to their emergence. From this perspective we could say, for example, that innovation comprises the development of ideas, turning these ideas into concrete material artefacts, and using these to bring about new creativity and new ideas (Czarniawskia \& Joerges, 1996).

The mutual influences which actors continually undergo is what we will term agency (Lynch, 2007; Sewell, 1992). Agency describes the relationship, in every possible form, between one or more individuals and one or more objects. Agency is based on action which leads to reaction. The prime mover in this is the initiator of the action which brings about a change in the network (Callon, 1986). This does not mean, however, that the person within the network is the only source of influence. Although objects have a real influence on individuals, an object cannot bring about a change inside the network without human intervention.

The mutual influencing and creation of agency is what Latour terms assemblage (Latour, 2005). When such an agency exists between actors so that they appear to be acting as a single body, then punctualisation occurs: the objects or the individuals are seen as actors (Garud \& Karoe, 2001). With the help of the Actor Network Theory (ANT), this phenomenon can be used to explain political and social organisation (Fotaki et al., 2010). Although the ANT describes heterogeneity among the actors, it is assemblage, along with the difference in agency, which determines what is generally described as power or status. Through its ever-changing nature, assemblage allows an actor to initiate changes within the network and thereby influence other actors. Whenever we write about a political or social organisation within the network, we are referring to the relative positions of the actors with regard to each other in terms of the assemblage which has taken place in the past. Assemblage is a continually occurring phenomenon that takes place within the network. Assemblage is also one-off: because of the complexity of the network and the reciprocal influencing of inanimate and human actors, it is highly unlikely that exactly the same assemblage will happen twice. An actor derives legitimacy from the agency with other actors. These relations are constantly changing and so, therefore, are the inanimate and human actors. Any specific assemblage will therefore 
always be unique and result in a different outcome. These changing actors and their changing positions within the network create a dynamic within the network which is referred as translation (Callon, 1986; Latour, 2005).

\subsection{Equivocality}

With this definition of emergent change as assemblage processes in the previous section we can raise the question which variables drive assemblage processes. The work of Karl Weick may offer an answer to this question: the process of sensemaking. In his extensive work Weick (see for example, Vogus, Sutcliffe, \& Weick, 2010; Weick, 1996; Weick \& Quinn, 1999; Weick \& Roberts, 1993; Weick \& Sutcliffe, 2006; Weick, Sutcliffe, \& Obstfeld, 2000) provides a possible answer to the question regarding how organisational behaviour can change in an actor network. The reasons why actors adjust/adapt their behaviour to each other can be answered by studying Karl Weick's work. Actors act locally in a complex system with each other on the basis of a common identity which has developed historically. They do this without either knowing how the system continues to develop as a whole, or understanding the current state of the entire system (Law, 2004; Thietart \& Forgues, 1995, 1997). Weick supports this idea and claims that behaviour systems are based on inter-connected behaviour and not on inter-connected individuals. Individuals do not dedicate 'all' of themselves to a particular organisation; rather, they only give a part of themselves. Obligations and inter-connectedness are spread over different groups. Therefore the emphasis is more on the relations between the actors than on the individual actors themselves. The cognizant individual no longer has centre stage. Weick argues that variation in a social system produces other behavioural connections (Weick, 1979). This variation in turn produces what Weick calls equivocality. Weick views the process of organising in terms of evolution. The starting point for the process of organising is a situation in which people experience equivocality. According to Weick, the picture we do not want to conjure up through equivocality is that of an environment which is confused, uncertain and chaotic. On the contrary, we imagine an environment which has an abundance of possible connections which we impose on an equally abundant assortment of possible variables we have selected. Weick believes that the term 'equivocality' describes these nuances the most accurately. It is especially the sheer number and multiplicity of meanings we can apply to a situation which an organisation has to deal with. Equivocality only becomes apparent when people are preoccupied with the world around them, when they attempt to grasp it, study it and fashion it. Weick calls the behaviour through which people, as it were, 'grab hold of' a part of their environment and make it available for further inspection 'enactment'. Enactment is not the same as 'reaction'. It is the active process which enables people to focus on the world and thereby create experience. From Weick's point of view, this process precedes thoughts about reality. Acting and attention precede reflection.

Weick's concept of an enacted environment is not the same as the concept of the perceived environment. Weick points out that actors reach at least some degree of consensus about their behaviour and that they look for patterns which form the basis for phenomena, actions and events. These patterns are assumed to be independent of their interpretations. The outcome of enactment is formed by equivocal images which require meaning. Several interpretations provide meaning and in the second step of the evolution model - 'selection'- the number of interpretations is reduced. Useful interpretations can subsequently be stored for future use, just as natural selection preserves useful genes. In this context Weick talks about 'retention', that is the storing of useful interpretations in the memory. There are two feedback loops which emanate from retention: one feedback loop leads to enactment and the other to selection. This means that memory steers not only the attention and the actions of people ('enactment'), but also the interpretation of what they subsequently experience (selection). What individuals do depends on what they know about the environment. What individuals know about the environment is in turn determined by what they perceive. What individuals perceive depends on what they do. This closes the circle: the process of thinking and acting reinforces itself. Weick uses the term 'enacted environment' to describe this. People live in a world which they themselves have created by their own actions. This holds for the individual, such as the manager, who through his own actions creates a work environment for himself, which he himself reacts to. The organising process, however, is primarily concerned with collective processes in which people act interdependently (enactment), perceive and interpret (selection), and store images in their shared memory (retention). The collective process of organising always begins in situations that cannot be solved by existing routines. In the model the 'driving force' behind evolution can be found in the unconscious processes of acting and attention. This is where the raw material - i.e. equivocality - for sensemaking is made. Only then will it be possible to produce useful interpretations (Weick, Sutcliffe, \& Obstfeld, 2005).

We therefore suggest that equivocality is an important driving force behind the interactions and actions in organisations. It is the enacted environment which produces a type of order in an actor network which is changeable and diverse and which occurs spontaneously. Weick calls the process which creates an enacted environment sensemaking. Furthermore, this spontaneous self-organising activity is important for order, the continuous evolution 
of the system and the potential to create something new. However, we cannot predict the new order and in this sense the system is chaotic. In this sense the unpredictability and chaos make an actor network a complex system. The concept of sensemaking and the enacted environment also influence the way in which the manager's world of thought is disconnected from the reality of the actor network. The manager's actions are similar to those of any actor in that they are prompted by the desire to reduce equivocality in the environment.

Changes in organisational behaviour can take place because of variation in the actor network. This variation could be the replacement of the actors in the network or the production of new material artefacts. However, it could also be a change in the interests of an individual actor. Although the behaviour of individuals is largely determined by the actor network, we agree with Giddens that a person as someone who offers his services freely and is competent in his actions. This variation creates equivocality which means actors will focus on understanding and interpreting this. This sensemaking process is the raw material for new organisational behaviour and in turn will serve as a new source of variation which will allow the sensemaking process to continue. However, there is a limit to sensemaking; it cannot continue endlessly. New meanings must be congruent with the implicit goals of the organisation, that is, its continued existence and growth. Stacey (2006) maintains that these implicit goals are formalised in organisational themes. Organisational themes determine how sense is made in organisations and ensure that connected behaviour does not have a negative effect on the continued existence and growth of the network. On the other hand, the process of sensemaking will maintain these themes; they form the specific frameworks of meaning for human actions in organisations. We can therefore consider themes to be components of the web of meaning, in which actors are imprisoned as it were and act accordingly. On this basis, two types of change can be distinguished: changes in organisational behaviour, which take place within the framework of existing themes, and secondly, changes in organisational behaviour, whereby organisational themes themselves are the subject of change. We suggest that the latter form of change takes place when the continued existence and growth of the organisation is at stake. In this case, themes will be redefined so that the continued existence and growth of the organisation is safeguarded. How the themes are redefined and which themes will arise cannot be predicted.

\subsection{Sensemaking as Political Agency}

In previous two sections we have defined what change processes are and which variables drive these change processes. We addressed emergent change as the process of agency. In a network, influencing takes place between human actors by means of inanimate actors, the result being new inanimate actors. These inanimate actors are used over again by human actors to once again influence other human actors.

This leads to the question as to what it is that propels this influencing process which was our second question. In section 3.3 we argued that equivocality is an important driver of human action. Human actors will resort to taking action whenever equivocality arises. As we have seen in the ANT approach, the origin of action is to be found in the preservation of one's own interests. On this basis, we would argue that human actors resort to action whenever equivocality arises with regard to advancing the current interests they may have. Human actors, therefore, resort to action not only when it is clear that their own interests could be harmed, but also when there is the impression that these interests could be harmed. This impression evokes equivocality for the actors concerned. Therefore, when it comes to serving one's own interests, we can subdivide this equivocality into: 1)The equivocality of inanimate actors, and 2)The equivocality concerning the origins of these inanimate actors, i.e. the interests of the actors which these inanimate actors have constructed.

This subdivision shows that sensemaking is not only a process which leads to a reduction of equivocality, but also one which contains an important political component. People make sense of the world in terms of their own conscious or unconscious interests. As a result, we can describe sensemaking as a process whereby direction is given in terms of one's own interests and of the reduction of equivocality with regard to fulfilment of, or impingement on, these interests. Agency is therefore the process of mutual influencing in which human actors attempt not only to reduce the equivocality concerning any possible impingement on their own interests but also, a priori, to exert influence in order to defend these interests and so prevent possible equivocality.

If there is ambiguity or lack of clarity with regard to the present and future ability to advance and defend one's own interests, then this will in all instances cause those human actors in the network who are involved to react: they will attempt to remove the ambiguity. The organisation, considered as a social area, is therefore a constant re-ordering of human actors within the network which is itself maintained through human and inanimate actors continually identifying ambiguity and attempting to remove it. 


\subsection{Translation}

This process of agency can be referred to as translation, a notion which is central to the ANT approach. Translation can be described as the shifting or aligning of actors' interests in order to create a network of allies which protects their interests (Latour, 2005). An actor network is therefore not fixed, but dynamic and self-organising. The actor network is continuous because human actants leave the network and new human actants enter. In order to safeguard their interests, these newcomers, ensure that the actor network continues through expansion and materialisation (see for example, Doolin, 2003). This process of translation - in which endurance and expansion are the central ideas, and during which some existing actants disappear, others remain and new actants appear - ensures there is variation in the texts in the actor network. In Weick's view this creates equivocality, which forms the basis of the sensemaking process. Changes in the actor network are brought about by translation, which creates shifts in the connected behaviour in the actor network through the appearance of new actants and the disappearance of old ones. These shifts, however, will be limited because the underlying importance of translation focuses on the continuation and expansion of the actor network. Possibilities for translation are therefore limited; behaviour will only be accepted if it contributes to the continuity and expansion of the actor network. Although there are a number of significant similarities between the work of Giddens, Weick and the ANT approach, the latter places more emphasis on connected behaviour as a linguistic process in which both acting and speaking (discourse) are seen as a basis for sensemaking. In Weick's view, actors make 'sense' of actions which have occurred in the past, whereas for ANT researchers, actors make 'sense' in conversations based on their interpretations of events in the present and the past. Setting these differences aside for a moment, we can conclude that connected behaviour and its outcomes - both in terms of acting and in material terms - provide an environment for sensemaking and that these new frameworks of meaning in turn influence actions.

The first step within this translation is described by Callon (1986) and Latour (2005) as opinion-forming. In this phase, the present network is examined to determine the legitimacy of the new inanimate actors. Although new human actors can also assume a role in a network, the perplexity phase is one in which the new human actor is not yet present. It is during this first phase that the future arrival of a new human actor is announced, whereby we can talk of an idea or message being presented as an inanimate actor. The potential place which the inanimate actor can take is partly determined by prejudices. If no legitimacy can be established, the translation will not take place. If legitimacy is established, the actor is then introduced into the network. Once a new person is in the network, then the inanimate actor becomes a human one. In this phase, that of introduction, agency occurs with other actors and the process of translation begins during which the initial position of the new inanimate actor is arranged. Once the position of the actor has been determined, it is included in the existing structure - the influencing phase. The position of the actor in the network thus becomes clear. It is during this phase, however, that the newly-established order resulting from the presence of the new actor may provoke the strongest resistance. The final phase, that of acceptation, can be described as the institutionalisation of the position of the actor within the network. The position is formally fixed and made clear to the other actors in the network. During these phases the individual is continually in a state of acceptation or rejection, one which is constantly changing, particularly during the influencing phase.

\subsubsection{Phase 1: Opinion-forming}

Translation begins with the forming of opinion concerning the removal or addition of an actor. Both cases will provoke a reaction which we describe as opinion-forming. In many ways this phase resembles the definition of Latour's perplexity phase and, to a certain extent, that of Callon's problematisation phase. Both definitions describe this phase as a consideration of the situation or problem and the first stance taken by the human actor with regard to a future display of directed behaviour. When examining this phase in more detail, Callon describes changes in the human actor's behaviour which are already apparent. We suggest that these changes only occur when the opinion-forming phase has been completed and when an initial binary reaction (acceptance or rejection) has been formed in relation to the introduction of a new actor.

The opinion-forming phase begins with individuals weighing up an actor's inclusion in, or removal from, the network. Just as Latour, we suggest that a legitimacy needs to be defended for an actor to be added to or removed from the network. We see this as being first of all an individual assessment which can lead to a positive or negative opinion regarding legitimacy. This individual assessment can be initiated as a result of an identified change within the network, or the individual's intrinsic need to change the network. In both cases consideration is given as to whether the change to the network benefits the advancement of individual interests. 
Opinion-forming is a preparation for the introduction of the actual actor into the network. The individual anticipates the outcome of this introduction and considers whether the introduction or removal has any effect on individual needs. The perceived organisation of the network plays an important role in these considerations.

\subsubsection{Phase 2: Introduction}

The actor reaches the introduction phase if he has considered how the introduction will take place and what interaction he will undertake initially. The introduction of an actor within the network gives other actors the opportunity to go through the opinion-forming phase and to anticipate how personal needs can be advanced after the introduction of the new actor. This phase has many similarities to Latour's acceptation phase (Latour, 2005) and, to a certain extent to Callon's interessement phase (Callon, 1986). The latter phase differs in that it does not involve convincing others but simply introducing the actant within the network. In both phases, however, the essential point is the initial exposure of the new actor to the other actors within the network.

If we consider the individual as an assemblage of multiple actors which can be defined as ideas, actions and thoughts, whereby the unconscious and conscious can be considered separately, then there occurs in this phase the translation of the unconscious to reality. This approach, according to Lacan's thinking(Kenny, 1996), describes the agency between the conscious and unconscious.

The opinion-forming happens unconsciously, and the way in which the translation to reality occurs is a conscious one. Becoming aware of what one's own interests are can be seen as a response to the introduction of new actors in the network. The individual's conduct resulting from the introduction of the actor is thus expressed in the agency which the individual maintains with other actors. This explains changes in conduct resulting from the opinion-forming phase at individual level.

\subsubsection{Phase 3: Influencing}

Agency takes place once the actor has been introduced into the network. The interaction between the existing and new actors in the network is aimed at including new actors or removing old actors within the existing structures, in line with Latour's description of the third phase of his definition of the translation process (Latour 2005). Agency takes place between the actors present, as well as between these and the newly-added actors. This influencing phase can lead to the creation of themes in which the new actors will, for a while, be a prominent component of the network on account of the multiple agency occurring as a result. In this phase, agency leads to the first step in organisational translation, namely the forming of an opinion. The aim of the phase is to determine which position all of the actors will take in the network. This phase shows similarities with that described by both Latour and Callon during which new actors are exposed to the network and to the mutual influencing which takes place as a result.

\subsubsection{Phase 4: Acceptation}

The final step cannot really be seen as a phase since it describes a state which is the result of the process of opinion-forming, introduction and influencing. It describes the extent to which the position of the new actor has been accepted within the network. This also directly indicates that the state of acceptance has been present during the whole process of translation but has been constantly changing. Acceptation is the result of the interaction between individual opinion-forming and influencing within the network. This state has a direct relationship with individual opinion-forming since the introduction of an actor and the influencing undergone by the individual will create a reaction which leads in turn to the introduction of new inanimate actors such as ideas, thoughts and opinions.

\subsection{Translation as the Process of Emergent Change}

In section 3 we examined the process of sensemaking and agency. We found first of all that sensemaking is a process which is steered by equivocality with regard to the actor's interests; it is steered firstly through clarifying the consequences of agency for these interests and secondly through actively guiding their preservation and advancement. We proposed that the inclusion or exclusion of new actors leads to agency aimed at their inclusion or exclusion. This process leads to a change and a new order of agency, leading in turn to changes in the network of actors within the context of the organisation. This process of translation describes the process of emergent change. Variation therefore entails the inclusion or exclusion of actors and as such is the most significant driver of emergent change.

\section{Discussion}

\subsection{Introduction}

If we can draw this conclusion about organisational change, what can we say about planned change - which was the starting-point of this article - and the role of the manager himself? 
The themes of Actor Network Theory include a description of how behaviour and connected behaviour are organised hierarchically, how groups of actors are formed and to what extent actors are allowed to speak for each other. This explains how organisations can be a conglomerate of different groups and a collective entity at the same time (Robichaud, Giroux, \& Taylor, 2004). Concepts such as 'bottom-up' and 'top-down' are defined thematically and indicate in which part of the actor network variation is present and how organisational behaviour develops in the actor network. As a rule, these new connections will evolve according to the possibilities the organisation themes present and the extent to which the themes from the different parts of the actor network are similar. Themes are limited to parts of the actor network; they are the product of the sensemaking processes of the actors who belong to that part and they are also the input for the same sensemaking process. In this sense, themes in the organisation will merge with each other.

In summary, we can conclude that, from the perspective taken in this article, planned change is a semantic construct. In this respect, planned change is no different from any other type of change: it provides an answer to the equivocality which arises from variation in the actor network. What conclusions can we draw for the manager from all this? In line with Goldstein (Goldstein, 1995; Goldstein \& Hazy, 2008; Goldstein \& Hazy, 2006), we could comment on the influence which managers have on successful planned change and the dominant role they play in it. Change is not external to the manager himself; the manager is in fact part of the change process. Although the actions of the manager stem from the context for which he himself is partly responsible, we would stress - as does Giddens - that he has a certain degree of freedom to act. As we have seen in the ideas put forward by Giddens and the ANT approach, it is precisely this room for action which produces the possibility for variation and equivocality. An important characteristic of the manager as a leader is also incorporated in this: a leader is able to reduce the equivocality of his followers and by acting together with them can construct new meanings. This ability relates to Gioia and Chittipeddi's definition of managers as sensegivers (Gioia \& Chittipeddi, 1991).

\subsection{Managerial Implications}

Hence, in emergent change processes, managers are both sensemakers and sensegivers at the same time. This has consequences for the role of managers as change agents. We will list four managerial implications.

\subsubsection{Implication 1: Managers Are Limited in Their Influence}

Although some will argue that this perspective is only one of many regarding organisational change, we think it is essential to highlight its importance. This perspective reflects the limited influence which managers' actions have in the organisational context. Although these actions are limited, we would like to draw the following conclusions with respect to the role which managers have in a self-organising system. We would stress that fulfilling this role is a goal; ultimately it is the web of meaning in an organisation that also influences the actions of managers. Although we agree with fellow authors that the amount of freedom available for an actor to act should be specified as much as possible and that this specification should be appropriate to the particular situation, we believe emphasis should be given to the limits on our freedom of choice as well as the unconscious influence which every actor's behaviour has on our actions.. A manager's change in behaviour produces variation and with it the raw material for change. The degree of variation produced is limited by the web of meaning or rather the themes of the organisation. An understanding of the limitations and consequences of their actions will ultimately give managers insight into the possibilities which they may or may not have.

\subsubsection{Implication 2: Change Is Translation}

A further implication concerns the concept of change. Change is a translation process and we have described the four phases involved. The introduction of every new actor or the exclusion of an existing actor leads to translation in the network. We wish to emphasise in this regard that new actants can also be opinions or new ideas. Not only new technology or new people, but also newly introduced opinions and new ideas can lead to ambiguity which needs to be reduced. In the translation process new actants can be accepted or excluded. This is an important extension to van Weick's ideas, by which people organise themselves not only in order to reduce equivocality but also to reject variation, the removal of which will also reduce equivocality. Translation only takes place when new actors are accepted and a new agency comes into being.

\subsubsection{Implication 3: Acceptance of the Change Manager}

We can also consider managers who initiate changes as new actors in the network. Initiating changes is, after all, related to new ideas and different behaviour. Managers who are part of the network must therefore take account of the fact that through initiating changes they are bringing in new inanimate actors, causing equivocality and so inducing a process of translation. By doing so, they themselves undergo a translation process and as a result have 
agency with the other human actors in the network whereby affirmation or rejection can take place. The rejection of an inanimate actor, such as a change initiative by the other actors can have far-reaching consequences for a manager introducing a change initiative. Not only may the initiative be rejected, but this rejection can also lead to the rejection of the manager himself along with his legitimacy to initiate changes in the future. It is the significance which the manager receives through his actions and through making use of the inanimate actors in relation to the advancement of other actors' interests that is decisive for the acceptation or rejection by the network.

\subsubsection{Implication 4: The Focal Object of Equivocality Differs in the Translation Process}

An important condition for the affirmation of change in the network is the successful completion of the translation process. We have identified four phases in this process: Opinion-forming, introduction, influencing, and acceptation.

In the phase Opinion-forming an opinion is formed in the actor network as to whether the new actant should be accepted or rejected. The main consideration taking place here is whether the proposed change as inanimate actor is actually of importance to the other actors. The acceptance of a new actor during the whole translation process will only occur whenever the change can promote current interests. An important condition for this to happen is the actors' recognition that the current situation may be threatening the promotion of their interests. To make minds ripe for change, the introduction of a message which stokes equivocality and unrest can provoke agency whereby the current actors come to recognise that the current situation can threaten the promotion of their interests. Moreover, this message must bring about the agency needed to generate confidence in the manager and his change initiative in order for the manager to be accepted in the network. In practice, the introduction of the new inanimate actor can be in the form of an idea or rumour that something is going to happen. Rumours can be caused by putting information into the network from the external context. Through these newly introduced inanimate actors, opinions are formed. This phase is essential for a manager who is busy setting up a change process. Spreading stories which create a need or demand, and which allow the actors present to consider whether a new initiative can suit their interests, may make it easier for the actors present to accept new ideas for change.

If, in phase 1, the actors have made sufficient sense concerning the status of their interests and have developed the readiness to accept the change initiative, then the introduction of the change initiative can proceed. This is the phase of the Introduction. The acceptance of this initiative must firstly create sufficient confidence for the actors concerned to reduce the current situation of equivocation regarding the advancement of their interests. This also indicates that the change initiative must meet certain requirements. Firstly, the initiative must be clear enough for the actors to be able to relate it to the current situation of equivocality. Secondly, it is important that this change initiative gives the actors the confidence that it is serving their interests and can be given their initial endorsement. The final requirement is that the change initiative has sufficient ambiguity to allow the invited actors to enter into further agency in order to explore the initiative and to make sense of it. This process, whereby the change initiative is endorsed and further sensemaking is generated, forms the start of the transition to the next phase.

In the Influencing phase the agency process takes place during which actors, including the initiating manager, make sense of the content of the change initiative. In this phase the intentions of the change initiative as inanimate actor are translated into concrete actions. This translation process is a continuous one, during which the actors influence each other and negotiate with each other. The manager plays an important role in this process: he does not stand above the parties but is actively involved as an actor with his own interests, the furthering of which is principally driven by his own behaviour. What is particularly important is the need for the manager to establish a relation between his own interests - represented as the organisation's interests - and the interests of other actors, thereby enabling him to increase his own influence on the process of agency. The translation of the change initiative to concrete actions may also allow new inanimate actors such as structure and procedures to be introduced into the network whereby the concrete actions can be supported and anchored in the network. The successful adoption of the change initiative depends on the actions of the manager. Allowing agency sufficient time and space is important for the endorsement of the change initiative and translation to concrete actions, as well as for the endorsement of the manager himself by the network. Doing so enables the manager to increase his influence on the agency processes.

In the phase of Acceptation the change initiative undergoes further adoption as well as further translation into action. The manager can advance the adoption process by fostering agency, during which the tools needed to support this translation, such as structure and procedures, can be further developed.

\section{Conclusion}

In this article we have developed a perspective on organisational change processes. Using the perspective of the organisation as an actor network, we have argued that organizational change is self-organising and emergent. Having 
introduced the concept of sensemaking developed by Weick and his colleagues, as well as the Actor Network Theory, we used these two perspectives to acquire a deeper understanding of emergent change and planned change. From our examination of the two concepts, we came forward with four implications for managers who are about to bring change into an organisation.

An important outcome of this article is the identification of a number of limitations to the traditional view of the role played by managers in change processes, and the consequences these have for managers' behaviour. One important consequence is the need for the manager to take on the role of sensegiver whereby he sets the conditions for the sensemaking process among his followers. Using the perspective of the Actor Network Theory, we examined this specific sensegiving role of the manager and drew up a number of conclusions as to how the change process or translation process can be successfully accomplished.

Firstly, time and space play an important role in initiating agency and the sensemaking process: actors need both. This is consistent with the ideas offered from other perspectives such as cognitive psychology and educational psychology, in which the importance of time and a powerful learning environment are conditions for agency and sensemaking (Blomme, 2003). As a sensegiver, the manager needs to give these conditions serious consideration. If too much psychological pressure is put on the process, this will lead to agency between the existing actors which is focussed on resistance and rejection of a change initiative.

Secondly, it is important to realise that the translation process is emergent. This means ensuring that the process of agency has an unpredictable outcome. The translation of the change initiative into concrete action is shaped during the process of agency and sensemaking. Since actors in agency repeatedly create structural tools in order to deal with every instance of equivocality, the equivocality regarding the change initiative will diminish and be replaced by equivocality regarding other themes. In this way, the change initiative will become part of everyday actions. Moreover, the network actors involved will produce structures which are focussed on maintaining the new way of acting (Giddens, 1991). This new way will slowly become a routine one which deviates from that which preceded the translation process. This means that the manager in his role of sensegiver is not only promoting agency and sensemaking, but also giving attention and support to the development of structures and other means which can support these two processes.

This means in conclusion that that the manager not only needs to focus his actions on reducing his own equivocality but also on encouraging the sensemaking process of the other actors. The manager's actions are, therefore, not to do with directly aiming at the acceptance of the change initiative but to do with influencing the agency and sensemaking process by which the translation to concrete actions is made and during which the original principles and objectives of the change initiative can at some time be set aside.

We consider that this article and these conclusions have made a contribution to the current thinking on planned change. We have described the role of the manager in relation to emergent change and reflected on his role as sensegiver in the process of translation. With regard to the implications discussed, we would recommend research being carried out into the role of managers during the processes of translation as well as into their effectiveness in the process of agency and sensemaking. By gaining more insight into the processes of translation and by determining the characteristics which distinguish emergent actions at each phase, we can gain a clearer understanding of the phenomenon of planned change.

\section{References}

Abraham, R., \& Shaw, C. (1987). Dynamics: A visual introduction. In F.E. Yates (Ed.), Self-organizing systems (pp. 543-597). New York: Plenum.

Berger, P., \& Luckman, T. (1966). The social construction of reality. New York: Anchor Press.

Blomme, R. J. (2003). Alignement: een studie naar organiseerprocessen en alignement tussen individuele en Organisatiecompetenties. Groningen: Gopher Publishers.

Burrel, G. (1996). Normal science, paradigms, metaphors, discourses and genealogies of analysis. In S. R. Clegg \& C. Hardy (Eds.), The Handbook of Organization Studies (pp. 388-404). London: Sage Publications.

Burrel, G. (1997). Pandemonium: Towards a Retro-Organization Theory. London: Sage Publications.

Callon, M. (1986). Some elements of a sociology of translation: domestication of the scallops and the fishermen of St Brieuc Bay. In J. Law (Ed.), Power, Action and Belief. A New Sociology of Knowledge? (pp. 196-233). London: Routledge \& Kegan Paul. 
Child, J., \& Smith, C. (1987). The context and process of organizational transformation - cadbury limited in its sector. Journal of Management Studies, 24(6), 555-593.

Chiles, T. H., Meyer, A. D., \& Hench, T. J. (2004). Organizational Emergence: The Origin and Transformation of Branson, Missouri's Musical Theaters. Organization Science, 15(5), 499-519. http://dx.doi.org/10.1287/orsc.1040.0095

Collins, R. (1981). On the Microfoundations of Macrosociology. American Journal of Sociology, 86(5), 984-1014. http://dx.doi.org/10.1086/227351

Czarniawskia, B., \& Joerges, B. (1996). Travel of Ideas. In B. Czarniawskia \& G. Sevon (Eds.), Translating organizational change (pp. 11-48). Berlin: Walter de Gruyter.

Devos, G., Buelens, M., \& Bouckenooghe, D. (2007). Contribution of content, context, and process to understanding openness to organizational change: two experimental simulation studies. The Journal of social psychology, 147(6), 607-29. http://dx.doi.org/10.3200/SOCP.147.6.607-630

Doolin, B. (2003). Narratives of Change: Discourse, Technology and Organization. Organization, 10(4), 751-770. http://dx.doi.org/10.1177/13505084030104002

Drazin, R., \& Sandelands, L. (1992). Autogenesis: A Perspective on the Process of Organizing. Organization Science, 3(2), 230-249. http://dx.doi.org/10.1287/orsc.3.2.230

Drazin, Robert, \& Kazanjian, R. K. (1990). Research notes and communications: A reanalysis of Miller and Friesen's life cycle data. Strategic Management Journal, 11(August 1989), 319-325.

Fotaki, M., Böhm, S., \& Hassard, J. (2010). The failure of transition: Identities, ideologies and imaginary institutions in times of global capitalist crisis. Journal of Organizational Change Management, 23(6), 637-650. http://dx.doi.org/10.1108/09534811011084339

French, J. R. P., \& Raven, B. (1959). The bases of social power. In D. Cartwright (Ed.), Studies in social power (pp. 150-167). Ann ArborI: Institute for social research.

Garud, R., \& Karoe, P. (2001). Path dependence and creation. Mahwah: Lawrence Erlbaum.

Giddens, A. (1991). Modernity and Self-Identity. Self and Society in the Late Modern Age. Cambridge: Polity Publishers.

Gioia, D. A., \& Chittipeddi, K. (1991). Sensemaking and sensegiving in strategic change initiation. Strategic Management Journal, 12(6), 433-448. http://dx.doi.org/10.1002/smj.4250120604

Gleick, J. (1988). Chaos: The making of the new science. London: William Heineman.

Goldstein, J. A. (1995). The tower of Babel in non-linear dynamics: Toward a clarification in terms. In R. Robertson \& A. Combs (Eds.), Chaos in psychology and the life sciences (pp. 39-47). Mahwah: Lawrence Erlbaum.

Goldstein, J.A., \& Hazy, J. K. (2008). Editorial: Complexity and the Generation of Social Value. Emergence: Complexity and Organization (E: CO), 10(3).

Goldstein, Jeffrey A., \& Hazy, J. K. (2006). Editorial introduction to the special issue: From complexity to leadership and back to complexity. Leadership, 8(4).

Greenwood, R., \& Hinings, C. R. (1996). Understanding radical organizational change: Bringing together the old and the new institutionalism. Academy of Management Review, (4), 1022-1054.

Greenwood, Royston, Hinings, C. R., \& Suddaby, R. (2002). Theorizing Change: the Role of Professional Associations in the Transformation of Institutionalized Fields. Academy of Management Journal, 45(1), 58-80. http://dx.doi.org/10.2307/3069285

Hailey, V. H., \& Balogun, J. (2002). Devising context sensitive approaches to change: the example of Glaxo Wellcome. Long Range Planning, 35(2), 112. http://dx.doi.org/10.1016/S0024-6301(02)00045-6

Hales, C. (2007). Moving down the line? The shifting boundary between middle and first-line management. Journal of General Management, 32(2), 31-56.

Harisson, D., Laplante, N., \& St-Cyr, L. (2001). Cooperation and Resistance in Work Innovation Networks. Human Relations, 54(2), 215-255. http://dx.doi.org/10.1177/0018726701542004

Higgs, M., \& Rowland, D. (2001). Developing change leaders: Assessing the impact of a development programme. Journal of Change Management, 2(1), 47-64. 
Higgs, M., \& Rowland, D. (2005). All changes great and small: Exploring approaches to change and its leadership. Journal of Change Management, 5(2), 121-151. http://dx.doi.org/10.1080/14697010500082902

Kallunki, J.-P., \& Silvola, H. (2008). The effect of organizational life cycle stage on the use of activity-based costing. Management Accounting Research, 19(1), 62-79. http://dx.doi.org/10.1016/j.mar.2007.08.002

Kaulingfreks, R. (1999). Gunstige vooruitzichten; Filsofische reflecties over organisatie en management. Kampen: Agora.

Kenny, D. (1996). The design and analysis of social-interaction research. Annual Review of Psychology, (47), 59-86. [Online] Available: http://www.annualreviews.org/doi/abs/10.1146/annurev.psych.47.1.59

Knights, D., \& Willmott, H. (1989). Labour Process Theory. New York: Macmillan.

Latour, B. (2005). Reassembling the Social. An Introduction to Actor-Network-Theory. Oxford: Oxford University Press.

Law, J. (2004). After Method. Abingdon: Routledge.

Law, J., \& Hassard, J. (1999). Actor Network Theory and after. Oxford: Blackwell Publishers.

Linstead, S., \& Thanem, T. (2007). Multiplicity, Virtuality and Organization: The Contribution of Gilles Deleuze. Organization Studies, 28(10), 1483-1501. http://dx.doi.org/10.1177/0170840607075675

Lynch, K. D. (2007). Modeling Role Enactment: Linking Role Theory and Social Cognition. Journal for the Theory of Social Behaviour, 37(4), 379-399. http://dx.doi.org/10.1111/j.1468-5914.2007.00349.x

Marion, R., \& Uhl-Bien, M. (2007). Paradigmatic influence and leadership: the perspectives of complexity theory and bureaucracy theory. In J. K. Hazy, J. A. Goldstein, \& B. B. Lichtenstein (Eds.), Complex systems leadership theory (pp. 143-162). Mansfield: ICSE Publishing.

Maturana, H. R., \& Varela, F. J. (1987). The tree of knowledge: The biological roots of human understanding. Boston: Shambhala Publications Inc.

Mezias, S. J., \& Glynn, M. A. (1993). The three faces of corporate renewal: Institution, revolution, and evolution. Strategic Management Journal, 14(2), 77-101. http://dx.doi.org/10.1002/smj.4250140202

Miller, D., \& Friesen, P. H. (1984). A Longitudinal Study of the Corporate Life Cycle. Management Science, 30(10), 1161-1183. http://dx.doi.org/10.1287/mnsc.30.10.1161

Robichaud, D., Giroux, H., \& Taylor, J. R. (2004). The Metaconversation: The Recursive Property of Language as a Key to Organizing. The Academy of Management Review, 29(4), 617. http://dx.doi.org/10.2307/20159074

Sewell, W. H. (1992). A Theory of Structure: Duality, Agency, and Transformation. American Journal of Sociology, 98(1), 1-29. http://dx.doi.org/10.1086/229967

Sirmon, D. G., Hitt, M. A., \& Ireland, R. D. (2007). Managing Firm Resources in Dynamic Environments to create Value: Looking inside the Black Box. Academy of Management Review, 32(1), 273-292. http://dx.doi.org/10.2307/20159292

Stacey, R. D. (2006). Complexity and group processes: a radically social understanding of individuals. London: Routledge.

Stoker, J. I. (2006). Leading middle management: consequences of organisational changes for tasks and behaviours of middle managers. Journal of General Management, 32(1), 31-43.

Ten Have, S., Ten Have, W., \& Janssen, B. (2009). Het veranderboek: 70 vragen van managers over organisatieverandering. Amsterdam: Mediawerf.

Thietart, R.-A., \& Forgues, B. (1995). Chaos Theory and Organization. Organization Science, 6(1), 19-31. http://dx.doi.org/10.1287/orsc.6.1.19

Thietart, R.-A., \& Forgues, B. (1997). Action, Structure and Chaos. Organization Studies, 18(1), 119-143.

Tsoukas, H. (2003). New times, fresh challenges: Reflections on the past and the future of organization theory. In H. Tsoukas \& C. Knudsen (Eds.), The oxford handbook of organization theory: meta-theoretical perspectives. Oxford: Oxford University Press.

Tsoukas, Haridimos, \& Chia, R. (2002). On Organizational Becoming: Rethinking Organizational Change. Organization Science, 13(5), 567-582. 
Uhl-Bien, M., \& Marion, R. (2007). Paradigmatic influence and leadership: the perspectives of complexity theory and bureaucracy theory. In J. K. Hazy, J. A. Goldstein, \& B. B. Lichtenstein (Eds.), Complex systems leadership theory (pp. 143-162). Mansfield: ICSE Publishing.

Vogus, T. J., Sutcliffe, K. M., \& Weick, K. E. (2010, November). Doing No Harm: Enabling, Enacting, and Elaborating a Culture of Safety in Health Care. Academy of Management Perspectives, 60-78.

Weick, K. E. (1979). The social psychology of organizing. Reading: Addison-Wesley.

Weick, K. E. (1996). Drop Your Tools: An Allegory for Organizational Studies. Administrative Science Quarterly, 41(2), 301. http://dx.doi.org/10.2307/2393722

Weick, K. E., \& Quinn, R. E. (1999). Organizational change and development. Annual review of psychology, 50, 361-86. http://dx.doi.org/10.1146/annurev.psych.50.1.361

Weick, K. E., \& Roberts, K. H. (1993). Collective Mind in Organizations: Heedful Interrelating on Flight Decks. Administrative Science Quarterly, 38(3), 357. http://dx.doi.org/10.2307/2393372

Weick, K. E., \& Sutcliffe, K. M. (2006). Mindfulness and the Quality of Organizational Attention. Organization Science, 17(4), 514-524. http://dx.doi.org/10.1287/orsc.1060.0196

Weick, K. E., Sutcliffe, K. M., \& Obstfeld, D. (2000). High Reliability: The Power of Mindfulness. Leader to Leader, 33-39.

Weick, K. E., Sutcliffe, K. M., \& Obstfeld, D. (2005). Organizing and the Process of Sensemaking. Organization Science, 16(4), 409-421. http://dx.doi.org/10.1287/orsc.1050.0133

Yolles, M. (2006). Organizations as complex systems: An introduction to knowledge cybernetics. Greenwich: Information Age Publishing. 